\title{
Reverse flow in academic mobility from core to periphery: motivations of international faculty working in Kazakhstan
}

\author{
Jack T. Lee ${ }^{1,2} \cdot$ Aliya Kuzhabekova ${ }^{1}$
}

Published online: 17 November 2017

(C) The Author(s) 2017. This article is an open access publication

\begin{abstract}
Through expanding flows of labor and knowledge on a global scale, academics are increasingly mobile as higher education institutions compete for talent that transcends borders. However, talent often flows from the periphery to the core as scholars seek out employment in recognized institutions of higher learning in developed economies. This study examines faculty mobility in a reverse direction: from the core to Kazakhstan, the largest country in Central Asia. What factors persuade faculty members to relocate to Kazakhstan for full-time employment? What types of individuals pursue this relocation? Through interviews with international faculty members based in Kazakhstan, the study identifies push factors that trigger departure from one's previous country of residence: job market, unsatisfactory work conditions, age, and marital status. Alternatively, Kazakhstan attracts scholars via pull factors that include salary, sense of adventure, and the opportunity to build new institutions and programs as well as conduct research. Unlike previous studies that highlight boundaryless mobility and individual agency, this study reveals constraints that mediate international faculty mobility. Furthermore, salary plays a limited role as a pull factor particularly among early career academics who are seeking research opportunities and meaningful contributions in building new academic programs and institutions.
\end{abstract}

Keywords Faculty mobility - Internationalization $\cdot$ Cross-border education · Transnational education $\cdot$ Academic labor $\cdot$ Migration

Jack T. Lee

J.T.Lee@bath.ac.uk

Aliya Kuzhabekova

aliya.kuzhabekova@nu.edu.kz

1 Graduate School of Education, Nazarbayev University, 53 Kabanbay Batyr Avenue, Astana, Kazakhstan 010000

2 International Centre for Higher Education Management, University of Bath, Bath BA2 7AY, UK 


\section{Introduction}

Over the last two decades, the internationalization of higher education has gained significant traction among policymakers, administrators, and researchers (Deardorff et al. 2012). Efforts to integrate an international perspective or activity into higher learning have led to initiatives such as student exchange, service learning, and international branch campuses. In the landscape of internationalization, the discourse continues to focus largely on student mobility and specifically on the flow of talent leaving the periphery (developing nations) to seek education at the core (developed nations) (Shils 1972; Altbach 1998a; van der Wende 2015). Less apparent in this discourse is the rapid internationalization of higher education in the periphery as systems expand to accommodate growing aspirations in economic development and educational attainment (Kehm and Teichler 2007; ADB 2011). These emerging configurations of higher education in the periphery often rely on internationalization such as the hiring of international faculty members who can introduce new courses and generate greater research output (Austin et al. 2014; Ruby et al. 2017). According to Altbach (2004), the bulk of new positions in academia in the near future will be in developing countries as their higher education systems expand.

This paper examines two issues neglected in the research on internationalization: (1) faculty mobility and (2) the case of Kazakhstan as a peripheral state that is actively pursuing internationalization. Specifically, this study identifies the motivations of international academics who relocate to Kazakhstan to take up full-time employment - a reverse flow of talent that contradicts most empirical studies of international mobility in higher education. The main research question asks: what motivates academics to relocate to Kazakhstan? Subordinate questions include the following: (1) What types of academics relocate to Kazakhstan? (2) What career aspirations inform these individuals' mobility decisions? This paper first provides an introduction to the internationalization of higher education in Kazakhstan with a focus on the creation of international universities. This background information is essential for understanding the current phenomenon of inbound faculty mobility. The paper then reviews the key concepts in literature on mobility among academics and other professionals before analyzing the motivations that drive academics to relocate to Kazakhstan. Finally, the paper reflects on faculty mobility in the direction of peripheral states with growing demands for higher education and discusses the implications for international higher education as academics seek non-traditional career pathways.

\section{Internationalization of higher education in Kazakhstan}

Kazakhstan has a history of actively internationalizing its higher education since gaining independence from the Soviet Union in 1991. In 1993, the government launched a largescale scholarship program, which continues to fund outbound student mobility today (Perna et al. 2015). Inbound student mobility remains low with students coming largely from Central Asia. Presently, the Bologna Process dominates the discourse on the internationalization of higher education (Yergebekov and Temirbekova 2012) such that many policymakers and administrators equate the two processes (Kovaleva and Lee 2016). The international universities identified in this section of the paper constitute the boldest strategies in the internationalization of higher education in Kazakhstan because significant resources are invested in institution-building and long-term planning. In 1992, Kazakhstan established a private, 
international university called KIMEP. ${ }^{1}$ This private university modeled after American higher education and began with faculty members recruited largely from outside Kazakhstan. For example, Canada's McGill University helped establish KIMEP's International Executive Center in 1998. The language of instruction at KIMEP is English. Shortly after creating KIMEP, the Kazakhstani government worked closely with the Turkish government to establish Ahmet Yesevi University and Suleyman Demirel University. These institutions affirmed the historical and cultural ties between the two countries. The next major new international university was established in 2000 with the leadership of the Aga Khan Development Network: University of Central Asia. The Kazakh British Technical University was established in 2001 through close partnerships between two governments. Stakeholders include the British Council, UK universities with expertise in mining, and several Kazakhstani government ministries and employers. In 2010, Kazakhstan made its most substantial investment in an international university by creating the Nazarbayev University (NU) as the flagship university of the country. NU touts close partnerships with University of Wisconsin-Madison, Cambridge, and the National University of Singapore. Faculty members at NU are largely expatriates who come from approximately 40 different countries.

Table 1 lists the universities in Kazakhstan that exhibit a significant international dimension. The table identifies the international dimension of each institution to provide greater clarity on the different interpretations of international. In some cases, the mere fact of using English as the medium of instruction automatically confers the label "international university." In other cases, the founding partners are foreign governments or international organizations. In creating these international universities, significant attention is focused on organizational structure and governance. Very little attention focuses on the professoriate who contribute to the critical success of these new universities. In a recent policy proposal, the Bologna Process and Academic Mobility Center of Kazakhstan set a goal of increasing the number of inbound foreign faculty by $10 \%$ each year (MES 2012).

\section{Literature review}

The literature on mobility among professionals is rapidly growing due to contributions from a wide array of disciplines: higher education, geography, human resource management, career development, and intercultural studies. However, empirical studies of faculty mobility can be found mainly in two disciplines: higher education and career development. These two fields approach faculty mobility from very different perspectives. Higher education often places the phenomenon in the context of internationalization while career development examines mobility in terms of individual experiences. Other fields such as intercultural studies and migration studies also occasionally examine faculty mobility but often peripherally from the lens of cross-cultural teaching (Dunn and Wallace 2006; Ghazarian and Youhne 2015) and labor market (Bauder 2012).

In our broad investigation of literature on faculty mobility, several studies from career development provide valuable conceptual ideas to stimulate reflections on higher education. The mobility of academics receives less attention in research than the mobility of corporate employees (Selmer and Lauring 2013). In general, studies on professional mobility consist of

\footnotetext{
${ }^{1}$ It is formerly known as the Kazakhstan Institute of Management, Economics and Strategic Research. This name was replaced in 2012 with KIMEP University.
} 
Table 1 International universities in Kazakhstan

\begin{tabular}{|c|c|c|c|}
\hline Institution & Est. & International dimension & Location \\
\hline KIMEP & 1992 & Faculty, programs, language (English) & Almaty \\
\hline Ahmet Yesevi University & 1993 & Partner (Turkey) & Turkistan \\
\hline $\begin{array}{l}\text { Suleyman Demirel } \\
\text { University }\end{array}$ & 1996 & Partner (Turkey), faculty, language (Turkish) & Almaty \\
\hline $\begin{array}{l}\text { Kazakh American } \\
\text { University }\end{array}$ & 1997 & Partner (USA) & Almaty \\
\hline $\begin{array}{l}\text { Kazakh American Free } \\
\text { University }\end{array}$ & 1997 & Faculty, partners (HEIs), and language (English) & Ust-Kamenogorsk \\
\hline $\begin{array}{l}\text { German-Kazakh } \\
\text { University }\end{array}$ & 1999 & Partner (Germany), faculty, language (German) & Almaty \\
\hline $\begin{array}{l}\text { University of Central } \\
\text { Asia }\end{array}$ & 2000 & $\begin{array}{l}\text { Partners (Aga Khan Development Network, Tajikistan, } \\
\text { Kyrgyzstan), language (English) }\end{array}$ & Tekeli $^{\mathrm{a}}$ \\
\hline $\begin{array}{l}\text { Lomonosov Moscow } \\
\text { State University }\end{array}$ & 2001 & Partner (HEI) & Astana \\
\hline $\begin{array}{l}\text { Kazakh British Technical } \\
\text { University }\end{array}$ & 2001 & Partner (UK), faculty, language (English) & Almaty \\
\hline $\begin{array}{l}\text { International Business } \\
\quad \text { School }\end{array}$ & 2008 & Partners (HEIs) & Almaty \\
\hline Nazarbayev University & 2010 & Faculty, partners (HEIs), programs, language (English) & Astana \\
\hline $\begin{array}{l}\text { Sorbonne-Kazakhstan } \\
\text { Institute }\end{array}$ & 2013 & Partner (HEI), language (French) & Almaty \\
\hline
\end{tabular}

"Language" means the medium of instruction either partially or fully as mandated in academic programs

${ }^{a}$ This is one of three campuses. The other two are located in Khorog, Tajikistan, and Naryn, Kyrgyzstan

two methodological approaches: (1) examine diverse individuals who relocate to the same host country or (2) examine individuals who originate from the same country but disperse worldwide. Both approaches have their strengths and weaknesses as researchers attempt to control a variable (host or home country) in order to emphasize either brain drain or brain gain. For example, one study examined 30 British academics who work around the world (Richardson and McKenna 2002) while another examined foreign academics who work in South Korea (Kim 2016). This literature review first covers scholarly works that deal with internationally mobile academics followed by studies on mobile professionals in general.

\section{The context of higher education}

Faculty mobility is one form of mobility that supports transnational higher education (Knight 2008). New international branch campuses and transnational degree programs often require mobile academics to teach. Many established universities are also recruiting from abroad to attract talent and diversify their campuses (de Wit 2002; Altbach 2004). While a number of studies have been conducted on mobile academics, these studies are largely about individuals who migrate to North America to work in established universities - particularly international students who completed their doctorates in USA and subsequently immigrated (Roh 2015). A few studies examine foreign academics working in the UK (Gimenez and Morgan 2017). Overall, these studies on USA and UK examine issues such as cultural adaptation, work productivity (Mamiseishvili and Rosser 2010; Franzoni et al. 2014), job satisfaction and coping mechanisms (Collins 2008; Romanowski and Nasser 2015), and faculty retention 
(Lawrence et al. 2014). Well-established higher education systems naturally attract scholars from around the world without the need to actively recruit internationally.

Among the studies that examine international faculty members (IFMs) working in peripheral states, research on Asia and the Middle East is prominent because higher education is expanding in these two regions to accommodate growing populations and research aspirations. Both regions are also the most active locales for transnational higher education (Knight 2014). Among the reasons that motivate faculty to relocate internationally, the promises of adventure and intercultural exposure rank highest among participants in many studies (Richardson and McKenna 2003; Richardson and Mallon 2005; Austin et al. 2014; Chapman et al. 2014). Chapman et al. (2014) further differentiate adventure seekers into academic nomads and recent retirees, both of whom are more excited by the prospect of working internationally than worried about the effects of mobility on their careers. Related to this motivation is the desire for a life change, which is also important for some mobile academics (Richardson and Mallon 2005; Froese 2012). While salary is an important factor, it is not the primary reason spurring academics to go overseas (Ackers 2005; Richardson and Mallon 2005; Austin et al. 2014). Noticeably, the focus in many of these studies is often on greener pastures in the host country (i.e., pull factors) rather than the undesirable situations of a home country or previous workplace (i.e., push factors). In two studies on IFMs in South Korea, research participants cited poor job market back home as an important reason in going overseas (Froese 2012; Kim 2016). In another study on IFMs in the United Arab Emirates, some participants identified the heavy research demands in their previous jobs as a reason for leaving (Austin et al. 2014). Lastly, some academics leave their home countries to escape difficult professional and personal situations that include being denied tenure, work conflicts, and divorce-Chapman et al. (2014) labeled these individuals as "redemption seekers."

Beyond tangible push-pull factors, the demographic traits of mobile academics raise interesting questions about mobility. Different studies provide conflicting results on age and gender. In a large-scale survey of 4600 Indian academics working overseas, younger participants exhibited slightly higher tendencies to work abroad than their older colleagues (Czaika and Toma 2015). Younger academics are also more motivated and adventurous than older ones in pursuing international posts (Selmer and Lauring 2010; Bauder 2012). However, one study found senior ranking academics more mobile perhaps due to the demand for seniority and expertise (van de Bunt-Kokhus 2000). Richardson and Mallon (2005) found no difference in mobility patterns among different age groups, between those with children and those without, and between genders. However, on the issue of gender, many studies showed a dramatic overrepresentation of men among internationally mobile academics. Women cited family responsibilities, sacrifices for dual-career relationships, and a desire for stability as key barriers in mobility (van de Bunt-Kokhus 2000; Myers \& Pringle, 2005; Selmer and Lauring 2010; Bauder 2012). Lastly, academics in technical fields such as science, engineering, and medicine as well as in English are more mobile than their peers in other disciplines given the global demand for technical expertise (van de Bunt-Kokhus 2000; Richardson 2009).

\section{The context of human resource management}

In the 1990s, Arthur (1994) proposed a new vein of research in organizational behavior and career development that would focus on "the unpredictable, market-sensitive world in which so many careers now unfold" (p. 297). At the time, research on traditional careers with 
prescribed responsibilities, hierarchical reporting, and long-term commitment towards one employer dominated the literature. Arthur and colleagues characterized "boundaryless careers" as those that transcended organizations and even industry sectors. While Arthur's conceptualization gave credence to individual agency, "boundaryless career" in the 1990s focused largely on inter-organizational mobility rather than international mobility. However, Inkson et al. (1997) soon created a comprehensive typology for internationally mobile professionals. The initiator of the mobility (organization or individual) delineates the categories in this typology. While this typology contains different forms of international mobility, the typology is less about diverse occupations and more about personal approaches to career development. The discussion section at the end of this paper will reflect on the relevance of this typology in higher education.

In many studies from the corporate sector, the term "expatriate" is used to label employees who work internationally (Andresen et al. 2015). Expatriate is generally defined as those who relocate across national borders, change their dominant place of residence, and hold legal work status (Boyle et al. 1998; United Nations 1998). In more nuanced analyses, several authors point out the need to differentiate the types of mobile professionals: assigned expatriates (AEs), self-initiated expatriates (SIEs), and migrants (Briscoe et al. 2009; Al Ariss 2010; Baruch et al. 2013). AEs are employees dispatched by companies to offshore branch offices; SIEs are individuals who actively seek out employment overseas; and migrants are individuals who move due to economic and political upheaval (Froese 2012; Andresen et al. 2015). Most research studies on expatriates tend to focus on AEs rather than SIEs (Crowley-Henry 2007).

It is important to note that some studies avoid using the term "migrant" when referring to professionals because it suggests involuntary mobility or illegal status (Suutari and Brewster 2000; Al Ariss 2010; Biemann and Andresen 2010). Migration studies is also a completely different field that tends to focus on low-skilled workers driven by economic prospects, refugees fleeing conflict zones, or immigrants seeking permanent relocations-again, these are very different narratives compared to those found in the literature on faculty mobility. Rather, the category that most accurately describes the type of mobile academics we are studying in our project is SIE. One may argue that mobile academics are in fact migrants fleeing poor job markets or political strife; however, this is an assumption that lacks resonance with the literature on faculty mobility and the empirical data from our study. While we did not pre-select participants based on motivations for moving to Kazakhstan, no participant identified economic or political hardship as a reason for their relocation.

\section{Definitions and parameters}

Two key terms require clarification in this study to establish parameters for the research: faculty mobility and international faculty. Faculty mobility is defined as the movement of academics from one country to another for the purpose of work and professional development. Work includes teaching, research, consultancies, sabbaticals, and full-time employment. Professional development enhances skills in administration, research, teaching, and publishing. An international faculty member (IFM) is defined in this study as an individual who lives and works in a host country (Kazakhstan) without current or prior citizenship in the host country. In this study, we focus specifically on full-time employment in a foreign country as an extreme form of faculty mobility because such an endeavor requires greater commitment than other types of faculty mobility (e.g., selling one's house, uprooting family members, dealing with 
culture shock, and learning a new language). This type of mobility also involves greater professional and personal risks because the employer may be a relatively unknown entity; future employers may frown upon international assignments outside core Western nations; and the host country may be politically unstable. The two important criteria of full-time work and non-Kazakhstani citizenship eliminate visiting professors, individuals on sabbaticals, and Kazakhstani returnees.

\section{Research design}

This study uses a qualitative approach to uncover the meanings and purposes that underpin the phenomenon of international academic mobility. Qualitative research is well suited to examine the idiographic nature of human behavior (Guba and Lincoln 1994). Semi-structured interviews were conducted with 24 international faculty members who have been working in Kazakhstan for a minimum of 1 year on a full-time basis. Participants were selected by maximum variation sampling in order to diversify the following traits: age, marital status, discipline, rank, and home country. This form of purposeful sampling was done to minimize biases in the data, which may overrepresent a particular demographic group or a particular motivation for mobility. Theoretical sampling was also used in order to understand cases of mobility that puzzled us. For example, some participants left well-known institutions and research centers in the West or brought nontraditional families to a largely traditional Kazakhstan (e.g., common law or same sex partners). Among the participants, the following countries are represented: USA (9), Canada (3), Belgium (3), UK (1), France (1), Switzerland (1), Netherlands (1), Russia (1), Turkey (1), Uzbekistan (1), Kenya (1), and South Africa (1). Participants identified these places as their "main country" even though some have strong ties with other countries through birth, marriage, or education. Often the main country is the place where a person has long-term ties through residence and employment. For example, two participants, who are originally from the Middle East, identified USA as their main country given that their entire professional careers were built there. Overall, the participants work in social sciences (10), life and physical sciences (11), and humanities (3). Seven participants moved to Kazakhstan with family members. Only one participant has family members from Kazakhstan. Unlike other studies that contain numerous participants with family ties to the host country (Froese 2012), this study purposely excluded these types of participants in order to focus on net brain gain for a host country. In terms of academic rank, participants are full professors (3), associate professors (12), and assistant professors (9). Participants are in their 30s (9), 40s (5), 50s (5), 60s (4), and 70s (1). An attempt to balance the gender among participants was not successful given the large number of males in the expatriate academic community (Richardson 2009). The data here represent the views of 19 males and 5 females. Each participant is identified by a pseudonym to ensure confidentiality. In addition to theoretical sampling, data collection also used constant comparison and observed data saturation as valuable techniques of grounded theory (Corbin and Strauss 2008). Thematic analysis was done on interview transcripts to identify key push-pull factors in mobility (Baruch 1995).

\section{Findings}

In identifying the reasons for relocating to Kazakhstan, many participants first made references to personal and professional situations in their previous places of residence before identifying 
pull factors that attracted them to Kazakhstan. For this reason, we decided to use the push-pull framework that is common in the literature on mobility (Baruch 1995; Altbach 1998b; Bierbrauer and Pedersen 1996; Mazzarol and Soutar 2002). Remarkably, nearly $40 \%$ of the participants in this study had lived in two or more foreign countries prior to moving to Kazakhstan. While hypermobility was never a participant selection criterion, its prevalence among participants reveals both an affinity for international work and the realities of today's academic job market. Only five participants had never lived in a foreign country prior to moving to Kazakhstan.

\section{Push factors}

\section{Job market}

Unsurprisingly, one of the reasons to leave a country is the lack of employment opportunities. The surplus of doctorates in the USA and parts of Europe creates a very competitive job market in academe. In addition, cutbacks in higher education funding further exacerbate this situation by reducing the number of tenured faculty positions available. Therefore, many young academics must toil in contract positions (e.g., adjunct/sessional lecturer) with poor working conditions and limited future prospects. Some participants purposely wanted to avoid post-doctoral positions given their poor pay and limited exposure to teaching. Participants who work in humanities felt a dire shortage of jobs in their disciplines. One humanities scholar from Europe said,

Basically I have spent more than 10 years of my life working towards an academic career. At that point [when considering moving to Kazakhstan] I really didn't see an alternative. (Sven)

While the job market in academe is an important push factor in the context of USA (Froese 2012) and Europe, this issue overshadows other equally important factors. Faculty mobility is not simply a symptom of supply-and-demand imbalances in human capital. When asked what motivated them to leave their previous country of residence, less than half of the participants mentioned difficulties in finding a faculty position at home. Instead, participants identified a myriad of factors. These push factors never exist in isolation even though the text below presents each motivation factor separately. Instead, a person's reasons for mobility are often enmeshed with other push and pull factors.

\section{Unsatisfactory work conditions}

Another set of push factors relate to dissatisfaction at a previous place of employment. A few participants identified a high teaching load that prevented them from conducting research and developing as scholars. Often, these are small to medium-sized universities or community colleges that focus on teaching. An American faculty pointed out a mismatch between his research interests (largely international) and the provincial orientation of his previous university. Another participant identified a breach of trust at a previous workplace that compelled her to seek alternative employment despite already gained tenure. For some participants, workplace dissatisfaction led to a drastic decision to leave a previous career for academia. A researcher from a national laboratory in 
Europe noted the stifling environment of his previous workplace because the work was entirely applied research for the state:

I couldn't stay in my past job because I was unhappy. They were bullying me. It was a question of mental health, so I decided to leave my country. (Philip)

Instead, he longed for greater freedom and creativity in basic research in a university setting. Another participant left a long career in corporate consulting to pursue his new interest in teaching and working with students. Finally, one participant felt unfulfilled in American academia despite completing a post-doctoral fellowship at an Ivy League institution:

I was working for a lot of famous people and everyone was like: 'This is your destiny!' But I was pretty disillusioned by academia in the US... It's all about making a name for yourself... So, I began looking for international positions where I felt like I could make more of a difference. (Catherine)

\section{Age and marital status}

One of the interesting push factors is age combined with marital status. While this is not a location-specific factor, it is nevertheless a key reason that prompted many participants to uproot. One might assume that young academics would be more mobile especially those who are single and fresh out of graduate schools. In fact, participants in this study quickly dispelled this stereotype. Participants of all demographic stripes, including those in their $60 \mathrm{~s}$ and $70 \mathrm{~s}$ and some with several schoolaged children, point to age as a key push factor. For those in their $20 \mathrm{~s}$ and 30 s, youth and the lack of family obligations allow them to be highly mobile. This finding echoes previous studies that found self-initiated expatriates were mostly young adults eager to gain an international experience (Inkson et al. 1997). For older participants, the realization on good health and the lack of responsibility as empty nesters motivated them to explore the world before retirement. One unexpected finding is the views of those in their $30 \mathrm{~s}$ and $40 \mathrm{~s}$, who are married and sometimes with several school-aged children. For these participants, the young age of children actually work in their favor because relocation is not as disruptive to schooling as it would be for teenagers. More importantly, some of these academics specifically seek an international and intercultural experience for their young children. As one Canadian academic said, "I enjoy different parts of the world. When I was young, I grew up in Africa. I spent a few years where my grandparents were working in Africa. So, it's just sort of being in my blood" (Greg). As a hypermobile family, Greg's children are accustomed to international settings such that life in Canada seems bucolic now. Therefore, different age groups hold different rationales for relocation. Several participants noted the urgency of a "now or never" opportunity to leave their home countries for a new experience.

Together, these three issues represent the most common push factors that drove participants to leave their previous places of residence: job market (system level), unsatisfactory work conditions (institutional level), and age and marital status (individual level). These levels reveal the complexity of push factors as well as differences in agency when considering relocation. System-level and institutional-level reasons are largely beyond the control of the individual. 


\section{Pull factors}

\section{Salary}

Salary is an important incentive as mentioned by some participants and affirmed by previous studies that examined the reasons behind expatriation (Inkson et al. 2004). Expatriate packages may include housing allowances, tuition for children, relocation cost, and annual return flights to one's home country. One participant mentioned salary as an incentive to leave a poorly paid post-doctoral position. Other participants viewed the salary and benefits package as compensation for Kazakhstan's geographic location:

I think salary is important. I mean in a way being so far away from the West... I think having this salary actually helps in terms of getting people to continue their networks. (Ethan)

Salary is pretty important. When you look up Astana in Wikipedia, it says it's the second coldest capital in the world. So you need some compensating factors to help. (Greg)

However, while generous compensation is an important incentive, most participants emphasized that salary was not the most important pull factor in the context of other pressing issues. In fact, some participants pointed out that their salary in Kazakhstan is actually comparable to their previous income. In competitive fields such as business, computer science, and engineering, participants noted that they could earn even higher salaries if they remained or moved into the private sector. One scientist dismissed the suggestion that money was an important pull factor:

Salary wasn't important. They [Kazakhstan] only matched my salary at home. They didn't give me $30 \%$ international bonus or whatever nonsense. That's OK because it didn't make any difference. I was going for experience not to make money. (Isabel)

This sentiment echoes findings from a large study of over 2000 New Zealanders working overseas, which identified non-economic factors as the most important reasons that motivate professionals to move (Inkson et al. 2004).

\section{Adventure}

If one were to select an attribute that defined all the participants in this study, it would be an adventurous spirit. The idea of relocating to Central Asia, a relatively remote region with limited visibility in international news and knowledge production, captivates many participants. For the vast majority of the participants, Kazakhstan and Central Asia are places of mystery.

I'm attracted to unknowns. Actually what attracted me is that there was not much on the internet about Kazakhstan - this worked in their [Kazakhstan's] favor... The less I know... that's something I think is fun. (Nathan)

It's an adventure. Every time I get to a point in my life where I had to make a decision I always choose the road less traveled. The road less traveled is more interesting. Why follow the footsteps of other people when you can forge an impact? (Lance) 
In Hofstede's (2010) research on cultural value orientation, participants like Nathan and Lance represent individuals with low uncertainty avoidance (i.e., high tolerance for uncertainty). Many participants mentioned family members and friends who expressed shock and confusion by their decisions to relocate to Kazakhstan. One engineer explained his curiosity which dates back to the Cold War:

I always had this curiosity about Soviet Union and being part of that was really attractive for me. I was a young socialist at that time. And they wouldn't let us visit. What is the socialist structure? How does the system work? What was it? A lot of these things were always in the back of my mind. That was the real attraction of coming here. (Eduardo)

For some participants, their desire to experience Kazakhstan first hand superseded even negative associations with the country:

Most of my British friends and my Canadian friends said, "It's going to be exciting! It's so different!' But most of my Polish friends said: "Why, why, why are you going to Kazakhstan?" Because in Poland, Kazakhstan is associated pretty much with Stalinist deportations of the $30 \mathrm{~s}$ and $40 \mathrm{~s}$ - very negative associations. (Boris)

I didn't know a lot about any of the Stans. I was interested in post-Soviet countries. I was really curious about what they were doing, and Kazakhstan had been in the news increasingly because of Borat. It was something through the New York Times and so forth, and I went to read more about it... There was a certain exotic element to it. (Igor)

In short, representations of Kazakhstan and Central Asia act as positive pull factors even if they generate negative connotations in mass media. Similarly, in one large-scale study of over 2000 New Zealanders working overseas (Thorn 2009), participants ranked "opportunities for travel" (sub category: adventure) as the top motive for expatriation. The implications of this kind of pull factor will be discussed later in this paper.

\section{Building new institutions and programs}

Related to the promise of an adventure, one of the most cited pull factors is the opportunity to build something new: a new academic program, a new department, or even a new university. This is a pull factor that may be unique to Kazakhstan due to its history in building new higher education institutions with significant international involvement. One participant fresh out of graduate school identified the opportunity that attracted him to Kazakhstan,

I liked the idea of getting to build a program in my field rather than just coming in and being a machine in an established place. I was attracted to being involved in a lot of things [in Kazakhstan] you otherwise don't get to be involved in. That was really exciting to me. To me, faculty positions in the US at the time just didn't appeal to me and sounded boring. (Oliver)

Many senior participants have extensive experience in building new programs and institutions. They specifically seek out work in peripheral countries:

It just seemed like an opportunity given my experience that I could have an impact here- - that's what I wanted: a new country that was 19 years old. I said, 'Let's go!' I like to see things develop. (Sebastien) 
First factor is building a new school. ${ }^{2}$ I have done it a number of times. I also helped to reposition a school from a lower end oriented (pure teaching) to a globally research oriented and more ambition to become a top school. I had a number of offers - one of them was again to reposition a proven, existing school, which is interesting. But in some ways, it is more challenging because you have to change the culture. Here the challenge is you have to build something from scratch that has its own challenges. (Karl)

Therefore, this attitude is more than a penchant for adventure or a curiosity in Central Asia but rather an interest in engaging in meaningful work that contributes to institution building.

\section{Research opportunities}

Another critical pull factor is the opportunity to conduct research. This factor is particularly germane to two types of academics: (1) junior faculty members and (2) regional experts. With dwindling research funding in many institutions and countries and poor research infrastructure in others, the prospect of working at a place that is eager to invest in research appeals to many participants in this study. Early career academics are eager to build a publication record via tangible offers such as research startup grants. The limited research conducted on Kazakhstan and Central Asia also appeals to junior academics who wish to carve out a path in academe. In addition, some participants are regional experts whose research interests focus on Kazakhstan, Central Asia, or post-Soviet societies in general. For these experts, the opportunity to work as an academic in situ is irresistible; they are attracted less by research funding but more by the proximity to research sites. As one regional expert said,

The majority of my research is on Tajikistan. I look at things comparatively. Previously I wrote one research article that compared Kazakhstan, Kyrgyzstan, Uzbekistan and Tajikistan... So, my specific career goal was to become familiar with Kazakhstan to be able to do more research about it. (Mark)

I studied mostly Russia and Ukraine. And I have always wanted to move into more of Central Asia or Caucasus direction - basically to look at a part of USSR which I knew very little about. (Boris)

These regional experts often have valuable language skills and cultural knowledge that allow them to navigate Central Asia quickly and accrue more credibility for their work and career via lived experiences.

Overall, Kazakhstan exerts four key pull factors: salary, adventure, building new institutions and programs, and research opportunities. These factors appeal to personal interests and professional ambitions. Participants often identified two to three main factors out of this list in making their final decision to relocate.

\section{Discussion}

\section{Theoretical contributions}

To conceptualize and understand international faculty mobility from the findings in this study, the existing literature on mobile professionals stimulates reflection and query on two fronts:

2 "School" means an entire faculty unit dedicated to his field of study. For confidentiality reasons, the reference to his field was removed. 
the types of mobility and the push-pull factors. The participants in this study are largely selfdriven sojourners like the self-initiated expatriates in the corporate sector. SIEs pursue boundaryless careers, which afford more individual agency and autonomy as the employee changes employers and countries (Tung 1998). Inkson and colleagues' typology of international mobility among professionals can be readily applied to higher education to categorize the different forms of international faculty mobility today (see Table 2). Unfortunately, Inkson and colleagues have labeled the first type of individuals as "expatriates," a broad term that many scholars would apply to all four categories in Table 2. Nevertheless, the higher education equivalent of expatriates in this typology would be the administrators and faculty members who are dispatched from the home campus to manage international branch campuses. Secondment is essentially a visiting professorship or short-term sabbatical. "Free agents" and "overseas experience" are individuals who actively seek out mobility; however, the former is seeking career development while the latter is seeking adventure. We further expand this typology to reflect the risks that mobility introduces to one's academic career. "Expatriate" and "secondment" are very low risk given the organizational support available; these academics enjoy the security of a permanent position at a home institution. Free agents are exposed to greater risks without organizational support; however, these individuals still prioritize career development. Overseas experience individuals face perhaps the greatest risks to their academic careers because they may seek international and intercultural experiences at the expense of career development. Finally, these types of mobility often differ in a temporal dimension. The first two are often time limited and well defined while the latter two are often sporadic and unpredictable. These conceptual differences stimulate a more nuanced understanding of faculty mobility rather than assume homogeneity in mobility and motivations. The participants in this study resemble the free agents and overseas experience identified by Inkson and colleagues; these individuals pursue an extreme form of faculty mobility that entails great uncertainty and risks.

From this study, it is also clear that many IFMs do not have a boundaryless career as described in the literature on mobility among professionals. Baruch and Hall (2004) pointed out that academics are "free agents" and can move jobs and research projects easily between

Table 2 International mobility among professionals Adapted from Inkson et al. (1997) with applications for higher education

\begin{tabular}{|c|c|c|c|c|}
\hline & Expatriate & Secondment & Free agents & $\begin{array}{l}\text { Overseas } \\
\text { experience }\end{array}$ \\
\hline Initiated by & $\begin{array}{l}\text { Employer but with } \\
\text { individual volition }\end{array}$ & $\begin{array}{l}\text { Individual but } \\
\text { with employer } \\
\text { sponsorship }\end{array}$ & Individual & Individual \\
\hline $\begin{array}{l}\text { Career } \\
\quad \text { framework }\end{array}$ & Structured & Symbiotic & Planned & $\begin{array}{l}\text { Opportunistic } \\
\text { /serendipitous }\end{array}$ \\
\hline Career type & $\begin{array}{l}\text { Traditional } \\
\quad \text { organizational career }\end{array}$ & $\begin{array}{l}\text { Traditional } \\
\text { organizational } \\
\text { career }\end{array}$ & Boundaryless & Boundaryless \\
\hline $\begin{array}{l}\text { Higher } \\
\text { education } \\
\text { context }\end{array}$ & $\begin{array}{l}\text { Administrators and } \\
\text { faculty dispatched from } \\
\text { home campus to } \\
\text { international branch } \\
\text { campuses }\end{array}$ & $\begin{array}{l}\text { Visiting } \\
\text { professors; } \\
\text { sabbaticals }\end{array}$ & $\begin{array}{l}\text { Faculty members } \\
\text { seeking career } \\
\text { development via } \\
\text { international posts }\end{array}$ & $\begin{array}{l}\text { Faculty members } \\
\text { seeking } \\
\text { overseas } \\
\text { adventures }\end{array}$ \\
\hline Risk to career & Low & Low & Medium & High \\
\hline Duration & Time limited & Time limited & Sporadic & Sporadic \\
\hline
\end{tabular}


higher education institutions. The narratives of the participants in this study do not reflect such utopian privilege and freedom. Faculty mobility does not follow the same rules of mobility that exist in other professions (Bauder 2012). As Richardson (2009, p. 164) noted, "While academia (the science context) may encourage and support geographic flexibility, universities (the institutional context) often have rigid hierarchical structures and processes that do not recognize and/or reward experience from outside the host country (the national context)." This study shows that an academic career is both traditional and boundaryless. A career in academia often follows a prescribed pathway that is marked by performance milestones from post-doc to tenure. Push and pull factors shape this pathway. Whether it is the job market at home, family situation, or the opportunity to create a new academic program in Kazakhstan, these factors mediate mobility. Unless a faculty member is mobile for the sole purpose of seeking adventures, these personal and professional constraints limit individual agency. Pringle and Mallon (2003) insightfully point out that career theories often assume significant individual agency without recognizing structural constraints.

However, academia also affords greater flexibility than other professions in terms of the organization of work (e.g., time and place) and the nature of work (e.g., academic freedom). While previous generations of academics may remain at one university or country for their entire careers, this permanence is increasingly less common as universities pursue more fluid arrangements of employment. Scarce resources and intense competitions for talent encourage or even demand mobility among faculty members today. Many participants are assistant and associate professors in this study. Perhaps international faculty mobility is a rite of passage for contemporary academics rather than a voluntary pursuit? Contrary to a previous study that concluded that academics from developed countries are less pressured to move abroad compared to those from developing countries (Czaika and Toma 2015), the majority of the participants in this study come from North America and Europe. The simplistic binary between scholars from developed and developing countries in terms of mobility pattern is not evident in our study.

\section{Policy implications}

Given the diverse motivations that drive faculty mobility among the participants in this study, it is instructive for both universities and national policymakers to recognize that academics are not swayed by the same pull factor. For example, the rhetoric of a generous compensation package in both policy discourse and the literature appeals only to a segment of mobile academics. Perhaps academics who are near retirement age or financially struggling would value a high salary. This begs the question: are these the types of academics that Kazakhstan and other peripheral states wish to attract to strengthen their higher education systems? Granted, senior academics do bring tremendous expertise and vast networks of professional connections, but a narrow recruitment strategy is not helpful in meeting the diverse needs of a growing higher education system. Salary alone also cannot persuade academics who are seeking an adventure if they perceive Kazakhstan and Central Asia as stagnant places. By and large, the junior faculty members in this study did not relocate to Kazakhstan for the salary. The opportunity to conduct research and play a role in institution building far outweighs the financial incentives. This finding is notable in that the research environment and administrative environment in Kazakhstan must support excellence in research and institution building. If a junior faculty member cannot conduct research in Kazakhstan or contribute to institution building, he/she would leave as expressed by several participants in this study. Coincidentally, during the data collection for this study, Kazakhstan suffered a major currency devaluation 
in the autumn of 2015. Overnight, the Kazakh tenge dropped $23 \%$ in value compared to the US dollar. This incident introduced a quasi-experimental element to this study in that salaries suddenly plummeted. In interviews conducted after the currency devaluation, we gauged participants' reactions to this economic crisis. In multiple interviews, junior faculty expressed anxiety over potential budget cuts to research funding, which would negatively affect their work and career. Several junior faculty participants even lobbied their universities to protect research funding during this financial crisis without mentioning salary reductions. However, other IFMs particularly those with family dependents and financial obligations (e.g., mortgages) lobbied actively for salary readjustments. These events highlight the importance of research opportunity as a pull factor in attracting junior faculty members as well as the tenuous nature of brain gain for a country when brain circulation operates on a global scale (Tung 2008).

Interestingly, less than 2 years after the data collection for this study, nearly half of the participants in this study have left Kazakhstan. While this study does not explore the reasons these participants left, this outcome raises serious questions about the sustainability of recruiting and employing IFMs. While economic and political futures may be uncertain in many countries, universities can at least invest in retention strategies that support career development and success. Remarkably, no participant in this study mentioned any retention strategies evident at their institutions after they were recruited to Kazakhstan. If the study were conducted after the currency devaluation, salary would likely play a smaller role as a pull factor.

\section{Conclusion}

Universities should recognize that international faculty members have diverse motivations for being mobile. While salary is important, many other factors such as research opportunities, adventure, and building new programs and institutions attract scholars. Faculty mobility is more complex than a matter of supply and demand in the academic job market. For the interests of universities and national policymakers in Kazakhstan and other transition economies, this study provides succinct push and pull factors that lead to mobility in a non-traditional direction: from core to periphery states. While Kazakhstan may not be very visible in the international arena, the country touts a dynamic policymaking landscape that affirms a strong desire to change and improve society. From national policies to diversify the economy beyond hydrocarbons to initiatives that promote inclusive education, the intensity of reform can be overwhelming. In the last 3 years, Kazakhstan coordinated a nearly successful bid to host the 2022 Winter Olympics, orchestrated conflict mediations between Russia and other states, and constructed a massive site to host Expo 2017. These events illustrate Kazakhstan's eagerness to raise its visibility and participate in global affairs. For these reasons, Kazakhstan faces a tremendous window of opportunity to engage with the world in all sectors including higher education. In recruiting international faculty members, Kazakhstan could emphasize these dynamic changes in the country to attract talented scholars. Universities can also develop retention strategies that address the needs of international faculty members who seek meaningful work.

Open Access This article is distributed under the terms of the Creative Commons Attribution 4.0 International License (http://creativecommons.org/licenses/by/4.0/), which permits unrestricted use, distribution, and reproduction in any medium, provided you give appropriate credit to the original author(s) and the source, provide a link to the Creative Commons license, and indicate if changes were made. 


\section{References}

Ackers, L. (2005). Moving people and knowledge: scientific mobility in the European Union. International Migration, 43(5), 99-131.

ADB (Asian Development Bank). (2011). Higher education across Asia: an overview of issues and strategies. Manila: ADB.

Al Ariss, A. (2010). Modes of engagement: migration, self-initiated expatriation, and career development. Career Development International, 15(4), 338-358.

Altbach, P. G. (1998a). Gigantic peripheries: India and China in the world knowledge system. In P. G. Altbach (Ed.), Comparative higher education: knowledge, the university and development. Greenwich: Ablex.

Altbach, P. G. (1998b). Comparative perspectives on higher education for the twenty-first century. Higher Education Policy, 11(4), 347-356.

Altbach, P. G. (2004). Globalisation and the university: myths and realities in an unequal world. Tertiary Education and Management, 10, 3-25.

Andresen, M., Biemann, T., \& Pattie, M. W. (2015). What makes them move abroad? Reviewing and exploring differences between self-initiated and assigned expatriation. International Journal of Human Resource Management, 26(7), 932-947.

Arthur, M. B. (1994). Boundaryless career: a new perspective for organizational inquiry. Journal of Organizational Behavior, 15(4), 295-306.

Austin, A. E., Chapman, D. W., Farah, S., Wilson, E., \& Ridge, N. (2014). Expatriate academic staff in the United Arab Emirates: the nature of their work experiences in higher education institutions. Higher Education, 68(4), 541-557.

Baruch, Y. (1995). Business globalization the human resource management aspect. Human Systems Management, 14(4), 313-326.

Baruch, Y., \& Hall, D. T. (2004). The academic career: a model for future careers in other sectors? Journal of Vocational Behavior, 64(2), 241-262.

Baruch, Y., Dickmann, M., Altman, Y., \& Bournois, F. (2013). Exploring international work: Types and dimensions of global careers. International Journal of Human Resource Management, 24(12), 2369-2393.

Bauder, H. (2012). The international mobility of academics: a labour market perspective. International Migration, 53(1), 83-96.

Biemann, T., \& Andresen, M. (2010). Self-initiated foreign expatriates versus assigned expatriates: two distinct types of international careers? Journal of Managerial Psychology, 25(3-4), 430-448.

Bierbrauer, G., \& Pedersen, P. (1996). Culture and migration. In G. Semin \& K. Fiedler (Eds.), Applied social psychology (pp. 399-423). London: Sage.

Boyle, P., Halfacree, K., \& Robinson, V. (1998). Exploring contemporary migration. Harlow: Addison Wesley Longman.

Briscoe, D., Schuler, R. S., \& Claus, L. (2009). International human resource management (3rd ed.). London: Routledge.

Chapman, D., Austin, A., Farah, S., Wilson, E., \& Ridge, N. (2014). Academic staff in the UAE: Unsettled journey. Higher Education Policy, 27(1), 131-151.

Collins, J. M. (2008). Coming to America: challenges for faculty coming to United States' universities. Journal of Geography in Higher Education, 32(2), 179-188.

Corbin, J., \& Strauss, A. (2008). Basics of qualitative research: techniques and procedures for developing grounded theory. Thousand Oaks: Sage.

Crowley-Henry, M. (2007). The protean career: exemplified by First World foreign residents in Western Europe? International Studies of Management \& Organization, 37(3), 44- 46.

Czaika, M., \& Toma, S. (2015). Path-dependency in international academic careers. IMI Working Papers, 108, 2-31.

de Wit, H. (2002). Internationalization of higher education in the United States of America and Europe: a historical, comparative, and conceptual analysis. Westport: Greenwood Publishers.

Deardorff, D., de Wit, H., Heyl, J. D., \& Adams, T. (2012). The Sage handbook of international higher education. Los Angeles: Sage and the Association of International Education Administrators.

Dunn, L., \& Wallace, M. (2006). Australian academics and transnational teaching: an exploratory study of their preparedness and experiences. Higher Education Research \& Development, 25(4), 357-369.

Franzoni, C., Scellato, G., \& Stephan, P. (2014). The mover's advantage: the superior performance of migrant scientists. Economics Letters, 122(1), 89-93.

Froese, F. J. (2012). Motivation and adjustment of self-initiated expatriates: the case of expatriate academics in South Korea. The International Journal of Human Resource Management, 23(6), 1095-1112.

Ghazarian, P. G., \& Youhne, M. S. (2015). Exploring intercultural pedagogy: evidence from international faculty in south Korean higher education. Journal of Studies in International Education, 19(5), 476-490. 
Gimenez, J., \& Morgan, W. J. (2014). Academics across borders: narratives of linguistic capital, language competence and communication strategies. Globalisation, Societies and Education (online).

Guba, E. G., \& Lincoln, Y. S. (1994). Competing paradigms in qualitative research. In N. Denzin \& Y. Lincoln (Eds.), Handbook of qualitative research (1st ed., pp. 105-117). Thousand Oaks: Sage.

Hofstede, G. (2010). Cultures and organizations: software of the mind; intercultural cooperation and its importance for survival. London: McGraw-Hill.

Inkson, K., Arthur, M. B., Pringle, J., \& Barry, S. (1997). Expatriate assignment versus overseas experience: international human resource development. Journal of World Business, 32(4), 351-368.

Inkson, K., Carr, S., Edwards, M., Hooks, J., Jackson, D., Thorn, K., \& Allfree, N. (2004). From brain drain to talent flow: views of expatriate Kiwis. University of Auckland Business Review, 6(2), 29-40.

Kehm, B., \& Teichler, U. (2007). Research on internationalisation in higher education. Journal of Studies in International Education, 11(3/4), 260-273.

Kim, S. K. (2016). Western faculty 'flight risk' at a Korean university and the complexities of internationalization in Asian higher education. Comparative Education, 52(1), 78-90.

Knight, J. (2008). Higher education in turmoil: the changing world of internationalization. Rotterdam: Sense Publishers.

Knight, J. (2014). International education hubs: student, talent, knowledge-innovation models. Dordrecht: Springer.

Kovaleva, L., \& Lee, J. T. (2016). Higher education in Kazakhstan. In D. Neubauer, J. Hawkins, M. Lee, and C. Collins (Eds.), The Palgrave handbook of Asia Pacific higher education (pp. 653-663). Palgrave Macmillan.

Lawrence, J. H., Celis, S., Kim, H. S., Lipson, S. K., \& Tong, X. (2014). To stay or not to stay: retention of Asian international faculty in STEM fields. Higher Education, 67(5), 511-531.

Mamiseishvili, K., \& Rosser, V. J. (2010). International and citizen faculty in the United States: an examination of their productivity at research universities. Research in High Education, 51(1), 88-107.

Mazzarol, T., \& Soutar, G. N. (2002). "Push-pull” factors influencing international student destination choice. International Journal of Education Management, 16(2), 82-90.

MES (Ministry of Education and Science). (2012). Academic mobility strategy in Kazakhstan for 2012-2020. Astana: Ministry of Education and Science of the Republic of Kazakhstan.

Myers, B., \& Pringle, J. (2005). Self-initiated foreign experience as accelerated development: influences of gender. Journal of World Business, 40(4), 421-431.

Perna, L. W., Orosz, K., \& Jumakulov, Z. (2015). Understanding the human capital benefits of a governmentfunded international scholarship program: an exploration of Kazakhstan's Bolashak program. International Journal of Educational Development, 40, 85-97.

Pringle, J. K., \& Mallon, M. (2003). Challenges for the boundaryless career odyssey. International Journal of Human Resource Management, 14(5), 839-853.

Richardson, J. (2009). Geographic flexibility in academia: a cautionary note. British Journal of Management, $20(\mathrm{~s} 1), 160-170$.

Richardson, J., \& Mallon, M. (2005). Career interrupted? The case of the self-directed expatriate. Journal of World Business, 40(4), 409-420.

Richardson, J., \& McKenna, S. (2002). Leaving and experiencing: why academics expatriate and how they experience expatriation. Career Development International, 7(2), 67-78.

Richardson, J., \& McKenna, S. (2003). International experience and academic careers. Personnel Review, 32(6), $774-795$.

Roh, J. (2015). What predicts whether foreign doctorate recipients from U.S. institutions stay in the United States: foreign doctorate recipients in science and engineering fields from 2000 to 2010. Higher Education, 70(1), 105-126.

Romanowski, M. H., \& Nasser, R. (2015). Identity issues: expatriate professors teaching and researching in Qatar. Higher Education, 69(4), 653-671.

Ruby, A., Kuzhabekova, A., \& Lee, J. T. (2017). International faculty recruitment in Kazakhstan: The case of Nazarbayev University. In M. Yudkevich, P. Altbach, \& L. Rumbley (Eds.), International faculty in higher education: comparative perspectives on recruitment, integration, and impact (pp. 150-172). New York: Routledge.

Selmer, J., \& Lauring, J. (2010). Self-initiated academic expatriates: Inherent demographics and reasons to expatriate. European Management Review, 7(3), 169-179.

Selmer, J., \& Lauring, J. (2013). Cognitive and affective reasons to expatriate and work adjustment of expatriate academics. International Journal of Cross Cultural Management, 13(2), 175-191.

Shils, E. (1972). The intellectuals and the powers and other essays. Chicago: University of Chicago Press.

Suutari, V., \& Brewster, C. (2000). Making their own way: international experience through self-initiated foreign assignments. Journal of World Business, 35(4), 417-436. 
Thorn, K. (2009). The relative importance of motives for international self-initiated mobility. Career Development International, 14(5), 441-464.

Tung, R. (1998). American expatriates abroad: from neophytes to cosmopolitans. Journal of World Business, $33(2), 125-144$.

Tung, R. (2008). Brain circulation, diaspora, and international competitiveness. European Management Journal, 26(5), 298-304.

United Nations. (1998). Recommendations on statistics of international migration. Statistical papers series $M$, 58 , 1. New York: UN.

van de Bunt-Kokhus, S. (2000). Going places: social and legal aspects of international faculty mobility. Higher Education in Europe, 25(1), 47-55.

van der Wende, M. (2015). International academic mobility: towards a concentration of the minds in Europe. European Review, 23(S1), 70-88.

Yergebekov, M., \& Temirbekova, Z. (2012). The Bologna process and problems in higher education system of Kazakhstan. Procedia - Social and Behavioral Sciences, 47, 1473-1478. 